\title{
Gambaran Kadar Kolesterol Total Darah pada Mahasiswa Vegetarian Lacto-Ovo
}

\author{
${ }^{1}$ Regina Wahjoeni \\ ${ }^{2}$ Yanti M. Mewo \\ ${ }^{2}$ Michaela E. Paruntu
}

\author{
${ }^{1}$ Kandidat Skripsi Fakultas Kedokteran Universitas Sam Ratulangi Manado \\ ${ }^{2}$ Bagian Biokimia Fakultas Kedokteran Universtias Sam Ratulangi Manado \\ Email: reginawahjoeni13@gmail.com
}

\begin{abstract}
High level of total cholesterol in blood or known as hypercholesterolemia causes atherosclerosis or constriction of the blood vessels. Aterosclerosis is considering as an important factor in coronary heart disease event. Consuming food with high cholesterol plays an important role on elevating total blood cholesterol. Vegetarian has better health quality than meat-eaters. This group has lower total blood cholesterol, triglicerid and LDL compared to meat eaters. The pourpose of this study was to find out the description about total blood cholesterol level in vegetarian lacto-ovo students. This descriptive study was followed by 25 respondents total that consist of 14 male respondents (56\%) and 11 female respondents (44\%). The result of this study shown that 23 respondents (92\%) have normal total blood cholesterol level and 2 respondets (8\%) have borderline high blood total cholesterol level. According to the results, it can be concluded that the description of total cholesterol blood level in vegetarian lacto-ovo students mostly are in normal level.
\end{abstract}

Keywords: total cholesterol, vegetarian lacto-ovo students

\begin{abstract}
Abstrak: Kadar kolesterol yang tinggi dalam darah atau hiperkolesterolemia menyebabkan aterosklerosis atau penyempitan pembuluh darah. Aterosklerosis adalah faktor penting pendukung terjadinya penyakit jantung koroner. Mengonsumsi makanan dengan kandungan kolesterol tinggi berperan dalam terjadinya peningkatan kolesterol darah. Vegetarian memiliki mutu kesehatan yang baik. Kelompok ini memiliki kadar kolesterol total, trigliserol, dan LDL yang lebih rendah dibandingkan pemakan daging. Tujuan penelitian ini adalah untuk mengetahui gambaran kolesterol total darah pada mahasiswa vegetarian lacto-ovo. Penelitian ini bersifat deskriptif. Pengambilan sampel diambil dengan menggunakan metode total sampling. Penelitian ini diikuti oleh 25 orang responden yang terdiri dari 14 responden lakilaki (56\%) dan 11 responden perempuan (44\%). Hasil penelitian ditemukan 23 orang (92\%) dengan kadar kolesterol total normal dan 2 orang (8\%) dengan kadar kolesterol total pada ambang batas tinggi. Dari hasil penelitian ini dapat disimpulkan bahwa gambaran kadar kolesterol total darah pada mahasiswa vegetarian sebagaian besar memiliki kadar kolesterol total normal.
\end{abstract}

Kata kunci: kolesterol total, mahasiswa vegetarian lacto-ovo

Kadar kolesterol yang tinggi dalam darah atau hiperkolesterolemia dapat menyebabkan aterosklerosis. Kolesterol, lemak dan substansia lainnya menyebabkan penebalan pada dinding pembuluh darah arteri sehingga pembuluh darah terserbut menyempit. Proses ini disebut aterosklerosis. Penyempitan pembuluh darah ini menyebabkan aliran darah menjadi lambat bahkan dapat tersumbat sehingga aliran darah pada pembuluh darah koroner yang fungsinya memberikan oksigen ke jantung berkurang. Proses inilah yang menyebabkan terjadinya penyakit 
jantung koroner ${ }^{1}$. Menurut Saidi yang dikutip Muhammad kontribusi kematian karena penyakit jantung koroner terbesar berasal dari kenaikan kolesterol total ${ }^{2}$.

Berdasarkan laporan WHO yang dikutip oleh Brata pada 2002 tercatat sebanyak 4,4 juta kematian karena PJK akibat hiperkolesterolemia ${ }^{3}$. Menurut Survey Kesehatan Rumah Tangga yang dikutip Waloya T dkk, tahun 2004 prevalensi hiperkolesterolemia di Indonesia rentang umur 25-65 tahun adalah sebesar $1,5 \%$ dan prevalensi batas tinggi adalah sebesar $11,2 \%{ }^{4}$.

Dari studi yang dilakukan Fox dan Ward masyarakat saat ini telah menyadari bagaimana eratnya kaitan pola makanan dengan kesehatan yang baik serta pencegahan penyakit seperti penyakit degeneratif yang menyebabkan bergantinya pilihan diet yang awalnya daging menjadi sayur-sayuran yang dikenal dengan vegetarian $^{5}$. Hal ini dibuktikan dengan terus bertambahnya vegetarian yang terdaftar di komunitas Indonesia Vegetarian Society (IVS) yang pada tahun 1998 sebanyak 5.000 orang dan pada tahun 2000 meningkat menjadi 60.000 orang $^{6}$.

Vegetarian yang tinggal di negara maju umumnya memiliki mutu kesehatan yang baik salah satunya adalah angka obesitas yang rendah, serta angka kejadian penyakit jantung dan diabetes yang rendah ${ }^{7}$. Vegetarian lacto-ovo juga memiliki kolesterol total, triasilgliserol, LDL yang lebih rendah dibandingkan pemakan daging. Menurut penelitian yang dilakukan Gandhi et al pada empat kelompok yaitu omnivora, vegetarian lacto-ovo, vegetarian lacto dan vegan terdapat perbedaan yang signifikan untuk total kolesterol, LDL, dan triasilgliserol pada omnivora dan vegetarian lacto-ovo ${ }^{8}$ Namun, dibandingkan dengan menu makan pemakan daging, menu makanan vegetarian memiliki kadar energi dan nutrisi esensial yang kurang sehingga mereka yang membutuhkan diet energi tinggi seperti wanita hamil dan wanita menyusui berisiko tinggi terkena defisiensi mikronutrien ${ }^{7}$.

\section{METODE PENELITIAN}

Penelitian ini dilakukan pada bulan September 2015 sampai Januari 2016 di Universitas Klabat Airmadidi dengan populasi mahasiswa vegetarian lacto-ovo yang tergabung dalam komunitas medical ministry dengan jenis penelitian deskriptif. Pengambilan sampel menggunakan metode total sampling dan ditemukan sebanyak 25 orang responden Kriteria inklusi adalah yang bersedia menjadi responden dan yang telah menjadi vegetarian lacto-ovo selama sekurang-kurangnya enam bulan.. Penelitian ini bertujuan untuk mengetahui gambaran kadar kolesterol total pada mahasiswa vegetarian lacto-ovo.

Vegetarian lacto-ovo adalah responden yang sumber makanan utamanya dari tumbuh-tumbuhan dan produk olahan hewan seperti telur dan susu selama sekurang-kurangnya enam bulan.

Kadar kolesterol total darah adalah hasil pemeriksaan laboratorium melalui darah vena pada responden yang puasa 1012 jam. Pemeriksaan laboratorium dilakukan di laboratorium Prodia menggunakan alat Horiba ABX Pentra 400 Analyzer Automatic dengan kadar kolesterol total normal $<200 \mathrm{mg} / \mathrm{dL}$, ambang batas tinggi 200-239 mg/dL dan tinggi $>240 \mathrm{mg} / \mathrm{dL}$.

Data yang dikumpulkan diolah dengan menggunakan program MS Excel 2007 dan disajikan dalam bentuk tabel distribusi frekuensi.

\section{HASIL PENELITIAN}

Berdasarkan jenis kelamin, responden terbanyak dalam penelitian ini berjenis kelamin laki-laki dengan jumlah 14 orang (56\%) dan perempuan berjumlah 11 orang (44\%).

Berdasarkan kadar kolesterol total dalam darah, responden yang memiliki kolesterol total normal adalah responden yang paling banyak dalam penelitian ini yaitu 23 orang (92\%) dan responden yang memiliki kadar kolesterol total ambang batas tinggi 2 orang.

Berdasarkan hasil pemeriksaan laboratorium kolesterol total pada 
penelitian ini didapatkan nilai mean atau rata-rata adalah $153 \mathrm{mg} / \mathrm{dL}$ dengan nilai standard deviasi yaitu 28,87. Nilai median dan nilai modus yang didapatkan yaitu 146 $\mathrm{mg} / \mathrm{dL}$ dan $156 \mathrm{mg} / \mathrm{dL}$. Nilai range pada hasil pemeriksaan kolesterol total didapatkan nilai minimum $101 \mathrm{mg} / \mathrm{dL}$ dan nilai maksimum 215 mg/dL.

\section{BAHASAN}

Berdasarkan hasil penelitian, kadar kolesterol total dalam darah responden didapatkan bahwa dari 25 orang ditemukan kadar kolesterol total darah normal sebanyak 23 orang. Hal ini sesuai dengan penelitian yang dilakukan De Biase et al bahwa vegetarian lacto-ovo memiliki kadar kolesterol total yang lebih rendah dibandingkan non-vegetarian ${ }^{9}$. Namun pada penelitian yang dilakukan Deriemaeker et al tentang kolesterol total pada vegetarian dan non-vegetarian di atas 65 tahun, vegetarian memiliki kolesterol total lebih tinggi dibandingkan nonvegetarian $^{10}$. Ini sesuai dengan pendapat Baraas yang dikutip oleh Listiana bahwa pada usia semakin tua, kolesterol total lebih tinggi kadarnya dan bahwa usia dapat mempengaruhi kadar kolesterol total seseorang dikarenakan makin tua seseorang aktifitas reseptor LDL mungkin makin berkurang $^{11}$.

Salah satu faktor untuk mengontrol kolesterol total darah yaitu dengan menjaga pola makan. Menurut penelitian yang dilakukan Desti diet yang mengandung lemak jenuh meningkatkan kadar kolesterol total darah ${ }^{12}$. Sehingga langkah pertama dalam pendekatan untuk menurunkan kolesterol adalah mengurangi asupan lemak jenuh dan kolesterol ${ }^{13}$.

Faktor penting yang lain yang mempengaruhi kolesterol total adalah kebiasaan melakukan olahraga secara teratur. Menurut Fatimah dan Kartini, olahraga secara teratur bermanfaat dalam menurunkan kadar kolesterol total ${ }^{14}$.

Serat juga berperan dalam mengontrol kolesterol total. Dari sebuah jurnal mengenai serat makanan dan kesehatan, serat mampu mengikat lemak dalam usus dan mencegah penyerapan lemak oleh tubuh yang dengan demikian membantu mengurangi kadar kolesterol dalam darah ${ }^{15}$. Menurut penelitian yang dilakukan Sutiari dan Pamungkas yang dikutip oleh Ginta bahwa asupan serat pada kelompok vegetarian vegan maupun vegetarian lactoovo berada pada ambang batas normal bahkan berlebih ${ }^{6}$.

Pada penelitian juga didapatkan kadar kolesterol total dalam ambang batas tinggi sebanyak 2 orang. Sebuah penelitian yang dilakukan Mira didapatkan vegetarian tipe vegan memiliki kolesterol total dan kolesterol total lebih rendah dibandingkan vegetarian tipe lacto-ovo karena vegetarian lacto-ovo masih mengonsumsi produk hewani yang meliputi terlur, susu dan produk olahannya ${ }^{16}$. Menurut National Cholesterol Education Program yang dikutip oleh Mira, telur, susu dan produk olahannya tersebut mengandung lemak jenuh dan kolesterol serta jika dikonsumsi berlebihan maka dapat meningkatkan kadar kolesterol total $^{17}$.

Menurut Anderson yang dikutip Lina, kolesterol harus dikontrol secara rutin terutama bila seseorang mulai menginjak dewasa karena proses aterosklerosis sudah mulai terjadi sejak usia muda secara diamdiam. Apabila kolesterol normal pemeriksaan selanjutnya cukup dilakukan setahun sekali. Namun, bila kolesterol cukup tinggi, pemeriksaan harus dilakukan setiap tiga bulan sekali untuk mengevaluasi semua upaya pengendalian yang dilakukan selama ini. Bila perlu pemeriksaan diulang setiap bulan, apabila kadar kolesterol sangat tinggi ${ }^{17}$.

\section{SIMPULAN}

Berdasarkan penelitian yang dilakukan pada mahasiswa vegetarian lacto-ovo Universitas Klabat yang tergabung dalam komunitas Medical Ministry disimpulkan bahwa gambaran kadar kolesterol total darah sebagian besar (92\%) adalah normal (<200mg/dL) dan sisanya (8\%) dalam ambang batas tinggi (200-239 mg/dL). 


\section{SARAN}

Hiperkolesterolemia berhubungan dengan makanan, menambahkan variabel penelitian yang lain seperti daily food record akan beguna unuk mengetahui pola makanan dan makanan yang sering dimakan.

\section{UCAPAN TERIMA KASIH}

Ucapan terima kasih dismpaikan pada dr. Yanti Mewo dan dr. Michaela Paruntu serta pada semua pihak yang baik secara langsung maupun tidak langsung telah menumbuhkan ide atau gagasan dalam pemikiran penulis sehingga dapat menyelesaikan artikel ini.

\section{DAFTAR PUSTAKA}

1. Bahri A. Manfaat Diet pada Penaggulangan Hiperkolesterolemi. USU electronic journal. http://library.usu.ac.id/download/fk/gizibahri.pdf

2. Dewi S, Azrimaidaliza A, Idral P. Faktor Resiko Kolesterol Total Pasien Penyakit Jantung Koroner di Rumah Sakit Achmad Mochtar Bukittinggi. UNAD electronic journal

http://jurnal.fkm.unand.ac.id/index.php/jk ma/article/view/72

3. Brata HW. Hubungan Pola Makan, Obesitas, Keteraturan Berolahraga \& Kebiasaan Merokok dengan Kejadian Hiperkolesterolemia. USU electronic journal http://library.usu. ac.id/download/fk/gizi-bahri.pdf

4. Waloya T, Rimbawan, Andarwulan N. Hubungan Antara Konsumsi Pangan dan Aktivitas Fisik Dengan Kadar Kolesterol Darah Pria dan Wanita Dewasa di Bogor. Jurnal Gizi dan Pangan; Maret 2013 https://www.google.com/url?sa=t\&rct=j\& $\mathrm{q}=\&$ esrc $=\mathrm{s} \&$ source $=$ web $\& \mathrm{~cd}=8 \&$ cad=rja\&uact $=8 \&$ ved $=0$ ahUKEwjxzoHRk 7vKAhWICI4KHWrxBowQFghbMAc\&u rl=http\%3A\%2F\%2Fjournal.ipb.ac.id\%2F index.php\%2Fjgizipangan\%2Farticle\%2F download\%2F7243\%2F5659\&usg=AFQj CNFs8qnCIARitDQFSqmvvrHVjYXrXA

5. Fox N, Ward K. Helath, Ethics and Enviroment. A Qualitative Studies of Vegetarian Motivations. Apetite. Juni 2007; 50 (2008): hal. 422-9.
6. Ginta S, Effendi N, Dini L. Hubungan Asupan Zat Gizi dengan Trigliserida dan Kadar Glukosa Darah pada Vegetarian. Indonesian Journal of Human Nutrition. Juni 2015; 2 (1). hal. 48.

7. Sabate J. The Contribution of Vegetarian Diets to Health and Disease: A Paradigm Shift. The American Journal of Cinical Nutrition; 2003 http://ajcn.nutrition.org/content/ 78/3/502S.full.pdf+html

8. Gandhi P, Agrawal N, Sharma S. A Study of Vegetarian Diet and Cholesterol and Triglyceride Levels. Worldwide Journals. Oktober 2014 http://www.worldwidejournals.com/ijar/fil e.php?val=October _2014_1412180740_139.pdf

9. DeBiase S, Fernandes S, Gianini R, Duarte J. Vegegarian Diet and Cholesterol and Triglycerides Levels. Scielo. Brasil. Kardiologi. 2007; 88 http://www.scielo.br/scielo.php? script=sci_arttext\&pid=S0066782X20070 00100006\&lng=en\&nrm=iso\&tlng=en

10. Deriemaeker P, Aerenhouts D, De Ridder D, Hebbelinck M, Clarys P. Health Aspects, Nutrition, and Physical Characteristics in Matched Samples of Institutionalized Vegetarian and NonVegetarian Elderly (>65years). Biomed Central. Nutrition \& Metabolism. Juni 2011. [diakses 3 Januari 2016] Diakses dari

http://nutritionandmetabolism.biomedcentr al.com/articles/10.1186/1743-7075-8-37

11. Listiana L, Purbosari T. Kadar Kolesterol Total pada Usia 25-60. Electronic Journal UMSurabaya; Juni 2012. http://journal.um-

surabaya.ac.id/index.php/Health/article/vi ew/7

12. Desti N, Hidayat L, Setiyono A. Hubungan Kebiasaan Konsumsi Lemak Jenuh dan Obesitas Sentral dengan Kolesterol Total Dosen dan Karyawan Universitas Siliwangi Tasikmalaya 2012. Electronic Journal UNSIL; 2012 http://journal.unsil.ac .id/jurnalunsil-829.html\#

13. Yani M. Mengendalikan Kadar Kolesterol pada Hiperkolesterolemia. Jurnal Olahraga Prestasi. Juli 2015; 11 (2): hal. 3

14. Fatimah S, Kartini A. Senam Aerobik \& Konsumsi Zat Gizi Serta Pengaruhnya 
Terhadap Kadar Kolesterol Total Darah Wanita. Jurnal Gizi Klinik Indonesia. July 2011;23-27. http://ilib.ugm.ac.id/ jurnal/detail.php?datald $=11228$

15. Teknik Pangan. Serat Makanan dan Kesehatan. Electronic Journal UNIMUS; 2006 http://tekpan.unimus .ac.id/wpcontent/uploads/2013/07/SERAT -MAKANAN-DAN-KESEHATAN.pdf

16. Teknik Pangan. Serat Makanan dan Kesehatan. Electronic Journal UNIMUS;
2006 http://tekpan. unimus.ac.id/wpcontent/uploads/2013/07/ SERAT-MAKANAN-DANKESEHATAN.pdf

17. Listiana L, Purbosari T. Kadar Kolesterol Total pada Usia 25-60. Electronic Journal UMSurabaya; Juni 2012. http://journal.umsurabaya.ac.id/index.php/Health/article/vi ew/7 